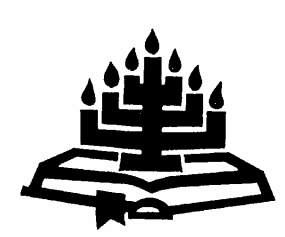

\title{
A practical theological narrative research of the adaptation process of a family that moved from South Africa to New Zealand
}

\author{
J. Reyneke \\ Department Practical Theology \\ University of Pretoria \\ PRETORIA \\ E-mail: nzreynekes@xtra.co.nz
}

\begin{abstract}
A practical theological narrative research of the adaptation process of a family that moved from South Africa to New Zealand

Using narrative research methods with an emphasis on the value of practical theological wisdom and an awareness of postmodernism and social constructionism as paradigmatic context, the adaptation process of the Vermaak (pseudonym) family after a move from South Africa to New Zealand, was explored.
\end{abstract}

Five major areas of their family life in which change occurred are discussed and their experience of God's involvement in the process is articulated. This understanding is enriched by an interdisciplinary inquiry which highlighted the process and the importance of the motivation for an overseas move as a helpful or hindering factor for meaningful adaptation. A brief mention of possible physical, psychological and social consequences is followed by a few comments that might be helpful to others.

The Vermaak family managed to strike a balance between the continuation of their past story and embracing their new context. This fact provides a hopeful anticipated future.

Opsomming

'n Prakties-teologiese narratiewe navorsing van die aanpassingsproses van 'n gesin wat van Suid-Afrika na NieuSeeland verhuis het

Deur gebruik te maak van narratiewe navorsingsmetodes, met die klem op die waarde van prakties-teologiese wysheid en die 
inagneming van postmodernisme en sosiale konstruksionisme as paradigmatiese konteks, is die aanpassingsproses van die Vermaakgesin (skuilnaam) nagevors.

Vyf belangrike aspekte van hulle gesinslewe, waarin daar verandering plaasgevind het, is bespreek en hulle ervaring van God se teenwoordigheid in die proses is verwoord. Hierdie begrip is verryk deur 'n interdissiplinêre ondersoek wat lig gewerp het op die proses en wat die belangrikheid van die motivering vir verhuising beklemtoon het. 'n Kort verwysing na fisieke, sielkundige en sosiale gevolge word opgevolg deur 'n paar opmerkings wat moontlik tot voordeel van ander kan wees.

Die Vermaakgesin het daarin geslaag om balans te vind tussen behoud van hulle verlede-verhaal en deelword van die nuwe konteks. Dit maak 'n hoopvolle, geantisipeerde toekoms moontlik.

\section{Introduction}

An Indian man sits quietly in the Heathrow Airport Terminal. He seems to look at something inside himself and his eyes are empty, inward looking. After a couple of days the terminal staff starts to notice him and ask what he is doing, why does he not go out and leave the terminal like all the other passengers? He answers that he has flown from Bombay to London and is now waiting for his soul to arrive (Antilla, 1995:77).

Adaptation in a new country can be described as the process of waiting for your soul to arrive, waiting for an inner peace and wholeness. For some, that never happens. For others, it takes three generations to be born into the new society, some are lucky enough that the process is quicker.

Due to various reasons many South Africans leave their country to live and work elsewhere in the world. New Zealand is one of these destinations. Since 1997 permanent residency in New Zealand was awarded to 23700 South Africans. In 2001/2002 South Africa was the country from which the fourth most immigrants (4 303) were allowed into New Zealand. The most were from China (8 750), then India (8 430), with Britain in the third place with 6593 (New Zealand Immigration Services, 2003).

The Vermaak family (not their real names) - being Wessel (41), Alet (38), Adriaan (13), Deon (10) and Janet (5) - also decided to move to New Zealand. It was a difficult decision that was only made after a lot of prayer and consideration. The decision was brought about because their life story got stuck. 
The stuckness for the Vermaak family occurred on various levels. In Wessel's general practitioner practice (situated in a poorer community) there was tension with the partner and the practice slowly became economically less viable. Wessel experienced considerable emotional turmoil about the inequality of the medical service he was able to provide to patients that could afford medical insurance and those that could not. Medical care was determined by the socio-economic situation of the patient. Patients that were members of a medical aid scheme could be prescribed better medication and could have medical procedures provided more quickly and of higher quality, but the rest could only afford basic medication and had to wait long periods before they could undergo medical procedures - often under questionable conditions.

The difficult circumstances under which Wessel worked had an influence on his family. He went home tired, preoccupied and irritable. He was not able to participate in many family activities and felt he was missing out.

At school all went fairly well, but there was uncertainty about outcome based education. There also was an unhealthy emphasis on achievement. A winning-at-all-cost-attitude caused pressure in the classroom as well as on the sport field. Often achievers got the bulk of attention and encouragement.

Even at church, the Gereformeerde Kerke van Suid-Afrika, there was struggle and questions were asked, while some left the church.

Alet managed to co-ordinate everything and keep everyone as happy as possible at home. But they were "stuck" and realised that they should contemplate alternatives. Many possible alternatives were considered and explored, but at the end they moved to Hawera, New Zealand, to start a new chapter in their lives.

The differences between South Africa and New Zealand, along with the leaving behind of everything familiar, posed a challenge to the Vermaaks. Will their South African souls arrive in New Zealand and what factors hinder or help the process?

\section{Discovering the story}

Before we continue with the Vermaak story, I would like to give some background on the research project. During the research there were issues that presented themselves for investigation and formulation. These will be briefly visited. 


\subsection{Paradigmatic context}

The paradigmatic context of the research, the researcher, as well as the co-researchers, is critical for understanding. It is important to be aware of your own positioning on the continuum as well as the positioning of those with whom you interact. It is helpful for understanding and a meaningful working relationship.

\subsubsection{Postmodernism}

We are living with the reality of a postmodern paradigm, which flowed from modernism, influencing our lives. Modernism and postmodernism have a conflict-laden co-existence that leads to heated debate, polarisation, uncertainty and even confusion and emotional numbness for the person without knowledge and insight into the phenomena (Pieterse, 2002:78-79; Janse van Rensburg, 2002:39-44; Strauss, 2002:570; Burr, 1995:12). With the vast variations in both these worldviews, it makes more sense to talk about a continuum.

Modernism emphasised human intellectual ability and had faith in technology and science to produce an utopia. There is confidence in knowledge; objectivity is both desirable and possible; foundationalism is the model for knowledge; the individual knower is the model of the knowing process and the structure of reality is rational (Erickson, 2001:73-74).

Postmodernism is not a homogeneous movement or philosophy (O’Donnell, 2003:6; Janse van Rensburg, 2002:39-42).

Postmodernism is concerned with non-linear, expressive and supra-rational discourses that have been marginalized and atrophied under the influence of the Enlightenment. ... Underlying everything is the belief that all human knowledge is limited and culturally conditioned: each age thinks in a certain way; humanity cannot help it. As a result there is no way to escape language, no way to stand outside discourse to get at pure, raw truth (O'Donnel, 2003:6).

O'Donnel (2003:29) compiles common denominators of postmodernism:

- Knowledge is limited to human discourse with no access to a reality "out there".

- Grand narratives, whether religious, philosophical or scientific, are limited and historically grounded. 
- Our generation is self-aware and knows that we are children of our times and play consciously with ideas and styles from other eras.

- There are competing claims on truth, types of discourse, forms of knowledge and lifestyles but still tolerance, openness and adaptability.

Within this tug of war between modernism and postmodernism I chose to make use of social constructionism as a meaningful frame of reference for understanding.

\subsubsection{Social constructionism}

Our selves, our minds - and indeed the society in which we live - are all co-created projects, never solo performances in which we have star billing and others are mere background. We celebrate the other, for without the other there is no existence of us either (Crocket, 2004:66).

Although unwise to try and define social constructionism, it is helpful to take note of important key assumptions (Liebrucks, 2001:365366; Burr, 1995:2-5):

- A critical attitude towards generally accepted knowledge.

- Views on reality are formed in the context of social interaction and are therefore historically and culturally relative.

- Social interaction forms social institutions as well as the individual. That means knowledge is sustained by social processes.

- Views on reality, that was socially constructed, play an important part in the (re)construction of institutions and persons. Knowledge and social action have an interactive influence on each other.

\section{Research approach}

Within this paradigmatic context I chose to do the research from a narrative perspective. Narrative research assumes practical theological wisdom (knowledge) of people to be a legitimate and rich resource for knowledge and understanding of certain experiences within a certain context. 


\subsection{Practical theological wisdom}

Modernism moved away from the oral to the written, from the specific to the universal (universally valid), from the local to the general (true in all contexts), from the time bounded truth to the timeless truth (Brueggemann, 1993:5). Postmodernism moved back to perspectivism. The constructing community determines the form, content, and boundaries of knowledge.

Even the industrial and economic sectors realised the importance of practical knowledge (Allee, 2000). Practical knowledge is knowledge that is embodied. It is bedded in a specific culture and based on a narrative unit. It is the continuity and whole of an individual or group (Clandinin \& Connelly, 2000:3, 17). It is the result of constant interaction between practical experience and current theory.

Practical theological wisdom adds faith and the Holy Spirit to the equation. The social constructionistic nature of practical theological wisdom is important. The individual, group, or community decide who has input (and also what kind of input) into the social construction and the practical theological thinking within a situation. The pneumatic dimension of a faith community must be accounted for. That implies theological texts (the Bible, creeds, etcetera) as well as theological tradition can play a role within a context and community, without falling into fundamentalism. Theological texts take the interaction between theory and practice serious.

Practical theological wisdom helps dissolve the dualism between praxis and theory by promoting the hermeneutic spiral movement between theory and practice.

\subsection{Narrative research}

Narrative research is one of the methods used to do qualitative research. There is no consensus on what exactly constitutes narrative research (Ollerenshaw \& Creswell, 2002:331).

In the light of the absence on consensus on what narrative research is, the three sets of criteria that McClintock et al. (2003) developed for the evaluation of research ("trustworthiness", "discourse validity", and "explicit frameworks") is very helpful and consistent with the narrative approach. I would like to add "ethical conduct". According to Shaw (2003:11), "Naïvete about ethics is itself unethical." Narrative research poses various ethical challenges throughout the research process. Therefore, the only sensible informed consent, is 
process consent which is a negotiated process that is ongoing throughout the course of the research (Smythe \& Murray, 2000:320).

Narrative research does not work with research subjects. Research is done with the people whose lives are researched and they are seen as co-researchers. Narrative research is the arduous task of discovering and excavating people's stories. With painstaking care the researcher and the co-researchers brush away debris to reveal different parts of the story. It is often required of the researcher and co-researchers to arrange the parts found in such a manner that it makes sense. Narrative research is therefore about the retelling of stories.

Restorying is the process of gathering stories, analyzing them for key elements of the story (e.g. time, place, plot and scene), and then rewriting the story to place it within a chronological sequence. Often when individuals tell a story, this sequence may be missing or not logically developed, and by restorying, the researcher provides a causal link among ideas (Ollerenshaw \& Creswell, 2002:332).

Because narrative research is so comprehensive, contextual, temporal and person, group or community specific, it is hardly possible to attend to more than one situation without the risk of losing nuances, dilemmas and contradictions that are part of individual stories (Gaddis, 2004:43).

I chose narrative research, because it moves away from generalisation and gives voice to unique individual stories. It shows respect for people and their lives.

\subsubsection{Research framework}

To adhere to the criterion of explicit frameworks as measure of valid research, I now briefly introduce the research framework used.

Müller (2004) developed a Postfoundationalist practical theology based on Wentzel van Huyssteen's Postfoundationalist theology (Van Huysteen, 1997).

The five elements of the Postfoundationalist practical theology were used as a research framework:

- The context and interpreted experience: description of specific context; in-context experiences are listened to and described; interpretation in collaboration with the co-researcher takes place. 
- Traditions of interpretation: The influence of discourses is investigated.

- God's presence: A reflection on God's presence as it is understood and experienced in the specific situation.

- Thickening through interdisciplinary investigation: Interdisciplinary enrichment takes place.

- Point beyond the local community: Development of alternative interpretations that may inspire understanding and change beyond the researcher and the co-researchers.

This framework has a logical flow that guides narrative research and enables a structured reporting of the research. Especially positive is the specific reflection on how God's presence is experienced by the co-researchers as well as the researcher within the researched story and the research process.

Within the limitations of an article, I now would like to try and describe the context and interpreted experience of the Vermaak family with a few general comments.

\section{Context and interpreted experience}

Although part of the global village, South Africa's isolation and then the sudden exposure to postmodern concepts and ideas since the mid nineties, as well as being part of Africa, make it an unique country with an unique worldview (see Du Toit, 2000:59; Müller, 1996:57; Pieterse, 2002:75).

New Zealand is a postmodern society with a relative short history and strong ties with Britain. Between 750 and 1000 years ago the first people arrived in wakas (rowing boats). Between 1642 and 1813 the European world "discovered" Aotearoa (land of the long white cloud). New Zealand was colonized since 1838. Immigration from many European countries had a definite influence.

The impressions South Africans have of New Zealand depend on many factors. Their emotional state, in which phase of adaptation they are, the reasons for moving to New Zealand, socio-economic situation, personal experiences, support system, and many other factors determine the description of the context. Place, time and person determine impressions.

On the far ends of the spectrum South Africans either interprets South Africa in a very bad light or New Zealand in a very bad light. 
Generally the person that wants to justify the emigration to New Zealand is the one that do some mud slinging at South Africa. They have to justify all the sacrifices, the yearning home, the adaptation stress, loneliness, struggle, and the financial, social, cultural, religious and personal losses that occurred. South Africa is then portrayed as a chaotic mess of crime and violence with a very bad, corrupt and incompetent government, which leads to the collapse of administration, education and the judicial system. Things like racial tension, the HIVIAIDS figures and unemployment is often exaggerated and the positive (like economic growth) is played down.

The negative perceptions of South Africa coincide with an overly favourable appraisal of New Zealand. On the other end there are those that have no good word about the Kiwis and their country. This is brought about by nostalgia, a misplaced love of their own culture, or a reaction against the exceptional pride and patriotism that the Kiwis have. The country and the weather are criticised and the Kiwis may then be depicted as less than efficient workers, arrogant and difficult to work with and to trust.

As far as interpreted experience is concerned it is important to note that for a viable future in a new country balance between stability and change is critical. It should be possible to continue enough of the old story while embracing the new (see Müller, 1996:116).

The homeostasis of the Vermaak family was disturbed. A few contrasts evolved:

- from patriotic South Africans, to people that apply for residency in New Zealand;

- from people who believed their calling is in Africa, to people with a calling in the "country of the long white cloud";

- from devoted Gereformeerde church members, to members of Baptist Hawera;

- from a positivistic Afrikaner way of rearing children, to a postmodern way of rearing children;

- from a marriage that made use of external support networks, to a self-maintaining marriage;

- from a family with an overworked dad, to a family that is closer to each other.

To reach balance it is necessary to remember the past, but to interpret it differently. In the end, the context and experiences lead 
to a redefining of the self. The Vermaak family had to let themselves be reconstructed. It is an exciting, difficult, constructive, tiring and continuous process.

This reconstruction process is greatly influenced by traditions of interpretation.

\section{Traditions of interpretation}

Interpretation traditions, or discourses, are "... a historically evolved set of interlocking and mutually supporting statements, which are used to define and describe a subject matter" (Butler, 2002:44). Put differently, "a discourse refers to a set of meanings, metaphors, representations, images, stories, statements and so on that in some way together produce a particular version of events" (Burr, 1995:48).

Discourses that were adhered to changed and were replaced by other discourses. The discourse that a good South African and a good Afrikaner does not betray his country and his people (past and present generations) by moving elsewhere, was replaced by the discourse that a South African can live and work in another country and still be proudly South African. The overwhelming importance of the family name, family tradition and church tradition made way for the stance that a person has the responsibility and duty to make decisions to secure a good future for the family and especially for the children. The belief that their calling was to make a difference in South Africa, in Africa, was enriched by the realisation that they may have a calling to be witnesses in New Zealand. It is possible to move to New Zealand and be a South African Kiwi.

There was a move from believing that the Gereformeerde church is the one and only true church securing you definite salvation, to seeing the body of Christ in a much broader perspective and becoming a meaningful part of a Baptist Church family. The importance that worship should be orderly, quiet and respectful was turned into a focus on the cause and not the form. A different, more unstructured way of worship is not necessarily less respectful and of lesser quality. The fact that there was no family church tradition to follow or to maintain, resulted in a honest reflection on their worship needs and personal needs and a subsequent search for a religious community that meet that needs. Their involvement in the Baptist congregation brought about one of the many wonders of the body of Christ - there was mutual enrichment and spiritual growth. 
The traditional Afrikaner discourses concerning the rearing and education of children were severely challenged in the new context. As opposed to an attitude that children should know their place, be seen and not heard, must be achievers, and do not question authority figures, the New Zealand context is extremely child orientated, valuing the child as unique with a potential that needs to be developed in order to give the child the best chance in life. Children are treated with respect, are taken seriously and are allowed to discover their uniqueness, celebrate that uniqueness and use it. Especially in the primary and intermediate years (Grade 0-7) the competition element is avoided or downplayed. In many ways children are treated as adults - with choices and in control of their own lives. They are often referred to as little people and not children.

Due to various reasons, Wessel and Alet used their extended families as support systems in such a manner that it deprived their relationship of a certain level of intimacy. The discourse that the breadwinner should come home to a peaceful environment and that the tired husband should not be bothered by trivial matters, resulted in the atrophy of emotional communication and subsequently in a diminished awareness of each other's emotions and feelings.

The reality of isolation changed these discourses and replaced it with the belief that the two of them are one and is suppose to be there for each other. This resulted in relationship growth.

Of great significance is the change in discourse as far as the man's role as provider is concerned. The discourse that the husband is the provider and the wife is the caregiver did not work any more. More important than the income and the subsequent lifestyle are family relationships. Who you are for your family, as father and mother, is what really matters.

The ignoring of the influence of one discourse in favour of the influence of another is not easy or instant. It is a process and most of the times there occur oscillations between two discourses until the new discourse are internalised.

\section{God's presence}

It was a particular privilege to be allowed on this holy ground and to contemplate, with the co-researchers, about God's presence during their process of adaptation in New Zealand. God's presence in the life of someone that acknowledges it, always has a big impact. Throughout history there were various symbols of God's presence in 
people's lives. There was a cloud (Ex. 16:10 ff.), fire (Ex. 3:1-4; Deut. 4:24; Heb. 12:29, etcetera), wind (Ps. 104:3-4) and other natural phenomenon, the soft whisper of a voice (1 Kings 19:12), a rock (Gen. 28:18; 35:14; Josh. 24:27 and others), the ark, the temple and many others. The sacraments, a church building, a cross, the Bible, nature, a wedding ring, Christmas, Easter, etcetera are contemporary symbols of God's presence. Each individual has unique symbols.

For Wessel and Alet one of the important symbols of God's presence in their family's life is their baptism - the sign that God has a lasting covenant, an agreement, to be their true, loyal and loving God. This meant that God guided them and was with them every step of the way - from the difficult decision up to the present - as always.

The move and adaptation catalysed spiritual growth. Their relationship with God became more intimate and dynamic. The realisation that God's calling is dynamic and may change was liberating. The dualism between religious life and everyday life were dissolved and faith became more practical than before. God's will for them, God's guiding presence, became nearly tangible through various experiences during the process. The Bible as one of the main sources of God's revelation of him-/herself always was of great importance to them.

A major aspect of God's presence was the Baptist Hawera congregation. Horizons were broadened, their understanding of the body of Christ metaphor was expanded and they experienced God's presence in a different part of the body and in a different style of worship. It is exciting to see the cross-pollination between two traditions and the enrichment that it brings. It is amasing to see the similarities and the vast amount of common ground that made it possible for the Vermaaks to become part of a community where they can live their faith.

\section{Interdisciplinary enrichment}

An effort was made to enrich understanding and interpretation of the adaptation process with insights from other disciplines, mainly psychology. The motivation for the migration plays an important part in the adaptation. 


\subsection{Reasons for migration}

In a study by Pernice et al. (2000) it was expected that South African immigrants to New Zealand, having a European and English language background, would do better in obtaining a job and have overall better mental health than the immigrants from China and India that also took part in the study. The South Africans were by far more successful in finding a job (83\%) as opposed to $11 \%$ of the immigrants from China and $25 \%$ of the immigrants from India. But they had the same mental health struggles.

It was expected that South African immigrants would have similarities with immigrants from Britain due to their cultural affinity with the majority of New Zealanders. The difference between South African and British immigrants may lie in the reasons for migration (Pernice et al., 2000:27).

In collaboration with Kunz's kinetic model (Kunz, 1973) Pernice et al., (2000) offers the difference between "pull" and "push" factors in the motivation for migration as explanation. On the one end of the continuum is the involuntary (forced) migration of a refugee and on the other end the "pull"-forces such as better work opportunities and a better lifestyle in the new country. Voluntary immigrants have the huge (psychological?) advantage that they can go back if they want to.

Most South Africans that participated in the study left South Africa because of "push" factors, like political instability, violence and crime. Other reasons are peace and stability, economic situations, quality of life, the education system, work opportunities, emigration as challenge and broadening of horizons, future for kids, health- and medical care, and social security (Wessels, 2001; De Freitas, 1999(b); Engelbrecht, 1998).

Although the "pull" factors in New Zealand are a reality, it is overshadowed by the "push" factors. That means most South Africans in New Zealand are semi-voluntary immigrants with ambivalent feelings about leaving South Africa.

Although they can go back, it is not that simple. To what will they go back? High unemployment is a reality. On the other hand some people left South Africa with such a flourish of trumpets about the utopia they were going to and the mess they were leaving behind, that it is psychologically impossible for them to go back. Sadly, in many cases financial realities make it impossible to consider going back. The Vermaaks were initially motivated by the "push" factors as 
mentioned before. This was balanced by the "pull" factors they encountered while Wessel was doing a locum for four months prior to their decision to move. They also did not burn any bridges when they left South Africa. That counts in their favour and helped their process immensely.

The support of their friends and family members that stayed in South Africa was very helpful to their process of adaptation.

\subsection{The process of adaptation}

De Freitas (1999a) uses William Bridges's (1980) model for life transitions and changes as framework as its simplicity makes it very useful. The process is divided into ends, the neutral zone and new beginings. It is also reconcilable with the narrative approach: the story gets stuck, the future story is obscured, the past story needs to be retold and reinterpreted which make it possible to live the present story with a good anticipated future story.

The ends usually consist of disengagement (a process of individuation), disidentification, disenchantment, and disorientation. The neutral zone is the time of adaptation and re-orientation. The new beginning would be the acculturation process, which is successful when a balance can be struck between the own culture and the new culture.

Bennet et al. (1997) warns that South Africans should not be misled by the apparent compatibility with New Zealand as far as language and culture is concerned. There are many factors to consider.

... geographical relocation has significant social, psychological and financial implications for migrant families. A broad range of stressors associated with relocation to another country has been identified. Some of the potential stressors are alterations in financial status, loss of close relationships, new recreational and educational patterns for children, pressure to succeed in a new job, establishment of new working relationships, housing problems, spouses' employment, community involvement, fear of the unknown, sense of isolation, new geography, new secondary relationships (e.g. doctor, church), new style of dress and language. For South African immigrants to New Zealand the social, economic and psychological costs may be higher than expected. Such costs may result in stress and the need for significant adaptation. Where costs are perceived to outweigh benefits, maladaption to the new environment may occur (Bennet et al., 1997:160). 
For successful integration of immigrants into New Zealand it appears to be necessary to take into account the degree to which the immigrants perceive themselves to have control over the relocation process as this may influence the coping strategy used to deal with any problems associated with the transition (Bennet et al., 1997:164).

It is clear that nobody will be able to go through the adaptation process unscathed.

\subsection{Possible consequences}

The effect of a migration on physical and psychological resources should not be underestimated. A long list of symptoms and diagnoses regarding mental health and cardio-vascular problems (Bennet et al., 1997:161; Eisenbruch, 1991:674; and others) as well as delayed bereavement (Renshaw, 1989:44) are reported.

The central problem for every immigrant is a transitory loss of stable identity, that is, the sense of one's continuous being as an entity, distinguishable from all others (Antilla, 1995:79). A stable identity needs at least spatial integration (mutual relationship of different parts of the self for the sake of cohesion), temporal integration (a connection of experiences over time for the sake of continuity) and social integration (projective and introjective identification with aspects of the self and others for the sake of a feeling of belonging).

Language plays an important role in identity and adults prove to have most resistance to change in this respect:

After I had lived in NZ for ten years I went back to visit my old country. I felt one of them, nobody noticed me, I was one of the crowd, it was wonderful. I was also surprised to find how easy it was to express myself, how little energy was needed for writing and talking and everyday life. I had been totally unaware how much energy I had spent by using English, which was my second language (Antilla, 1995:81).

Nostalgia is inevitable. Sohn (1983:203) distinguish between true and false nostalgia:

The Oxford English Dictionary definition of nostalgia is that it is a form of melancholy caused by prolonged absence from one's country and home, the word first appearing in the late eighteenth century, and being formed by the conjunction of two Greek words meaning a return to home and pain. 
This is not the version that the word nostalgia has been given in recent years. It has become an indication of almost a pleasant state of mind, easily attainable by artifacts and psycho-facts, which can be conjured up with relative ease, a process I assume designed to alleviate the underlying melancholy or yearning.

I think both are legitimate forms of nostalgia that present themselves under different circumstances. A painful nostalgia emerges when times are tough and often the past is remembered as better than it was. In times of disorientation nostalgia is a sign of resistance against change and a yearning for the stability of the past (Engelbrecht, 1998:260).

Children adapt quicker than adults and often more completely. This means that children soon start to live in two worlds - the own (old) culture and the new culture. This leads to intergenerational stress. At home the young people try to please their parents and outside they want to be acceptable to their peers (Renshaw, 1989). This sometimes makes children more susceptible to bad influences (Antilla, 1995).

\section{Beyond the local community}

The last movement of the research is an attempt to look beyond the local community, the people and context involved in the research. This is no generalisation. It would be impossible because every situation is unique and there is so many determining factors: The country and culture of destination, the financial ability (qualifications, job availability, etcetera) of the family, the support from friends and family, the support systems in the new community, the climate, the number of other South Africans living in the vicinity, the family culture (religious activities, adaptability, etcetera) and many other factors come into play. It is a cautious indication of aspects that might be meaningful beyond the context of the researcher and the co-researchers.

It is important to take note of the spirit of the age, the current worldview, the presiding discourses and philosophies, which influence the researcher and the co-researchers. Just awareness thereof brings new insight and understanding. This is especially true when moving from one country to another, from one culture to another. Awareness of the influence of discourses in one's life gives the agency to be able to resist it, when required. 
Social constructionism offers a framework for understanding of society, the self and interactions that take place. When it is held that the "truth" is determined and constructed by each group or community, it creates space for peaceful co-existence and a better context for debate when differences arise. It results in an accommodating, respectful attitude that promotes meaningful dialogue, because there is an empathic awareness of the others' context. A big contribution that social constructionism makes, is the prevention of total relativism. The constructing community sets boundaries. In a faith community God, Scripture, tradition and dogma are part of the constructing community.

Practical theology can dissolve the dualism between practice and theory by taking seriously the hermeneutic spiral movement between practice and theory (Browning, 1991; Müller, 1996; 2004; Viau, 1999). This can be done by a social constructionistic approach to the formulating of a theology and by exploiting practical theological wisdom.

It generally takes longer to return to a state of normality after an overseas move than after death of a loved one or divorce and there are potential negative long-term consequences. It is therefore preferable to consider the possibility carefully before doing it. Careful consideration of the reasons, the motivation for the move is very important. Be aware of the fact that negative factors ("push" factors) in the current situation as the only motivation may complicate adaptation.

The perception that you are in control of the process is helpful for the process of adaptation. This includes the possibility to go back. It would therefore be wise to go about the planning and execution of the move carefully and, if possible at all, ensure the emotional, social and financial possibility to be able to return.

Be prepared that the anticipated future in the new country will probably be a disappointment and disenchantment, because the reality cannot compare to the conscious and unconscious idealistic images that are created before the move. The new context causes discontinuity, and therefore congruency problems with the past. Meaningful adaptation requires a reinterpretation, a retelling of the past in order to connect with the present and anticipated future in the new country. For this the narrative approach is very helpful and provides a way to negotiate challenges. 
Faith and an awareness of being part of a worldwide faith community and a quick involvement with a new local faith community, provide much needed continuity and a sound support system.

Balance between that which was and that which is must be reached before there can be any mentioning of a successful adaptation in a new country. Enough of the old is necessary to embrace the new meaningfully. Energy and effort must be invested in relationships with friends and family in South Africa and relationships in the new context.

The Vermaak family managed to adapt to their new environment in New Zealand in a positive way and contributes to the community on various levels. This was by no means an easy accomplishment and is by no means a completed process. They constantly testify to the fact that it would have been much worse if it was not for their relationship with God.

\section{List of references}

ALLEE, VERNA. 2000. Knowledge networks and communities of practice. OD Practitioner Journal of the Organization Development Network, 32(4).

ANTILLA, O. 1995. Some thoughts on the process of immigration. Journal of the New Zealand Association of Psychotherapists, 1:77-85, Jun.

BENNETT, H., RIGBY, C. \& BOSHOFF, A. 1997. The relationship between tenure, stress and coping strategies of South African immigrants to New Zealand. South African Journal of Psychology, 27(3):160-165.

BRIDGES, W. 1980. Transitions: making sense of life's changes. London: SCM.

BROWNING, D. 1991. A fundamental practical theology: descriptive and strategic proposals. Augsburg: Fortress.

BRUEGGEMANN, WALTER. 1993. The Bible and postmodern imagination: texts under negotiation. Augsburg: Fortress.

BURR, V. 1995. An introduction to social constructionism. New York: Routledge.

BUTLER, C. 2002. Postmodernism: a very short introduction. Oxford: Oxford University Press.

CLANDININ, D.J. \& CONNELLY, F.M. 2000. Narrative inquiry: experience and story in qualitative research. San Francisco: Jossey-Bass.

CROCKET, KATHIE. 2004. From narrative practice in counselling to narrative practice in research: a professional identity story. The International Journal of Narrative Therapy and Community Work, 2.

DE FREITAS, J. 1999(a). Immigration: being lost enough to be found. Unpublished paper delivered at N.Z. Psychological Society.

DE FREITAS, J. 1999(b). Immigration: a process of transition, trauma and integration. Unpublished paper delivered at the N.Z. Psychological Society. 
DU TOIT, B. 2000. God? Geloof in 'n postmoderne tyd. Bloemfontein: CLFUitgewers.

EISENBRUCH, MAURICE. 1991. From post-traumatic stress disorder to cultural bereavement: diagnosis of southeast Asian refugees. Society for Scientific Medicine, 33(6).

ENGELBRECHT, A.S. 1998. The posttraumatic effects of criminal violence on the family. Port Elizabeth: UPE. (Ph.D. thesis.)

ERICKSON, M.J. 2001. Truth or consequences: the promise \& perils of postmodernism. Illinois: InterVarsity.

GADDIS, STEPHEN. 2004. Re-positioning traditional research: centering clients' accounts in the construction of professional therapy knowledges. The International Journal of Narrative Therapy and Community Work, 2:37-48.

JANSE VAN RENSBURG, J. 2002. Die postmoderne mens aan wie die evangelie verkondig moet word. Praktiese Teologie in Suid-Afrika, 17(2):39-60.

KUNZ, E.F. 1973. The refugee in flight: Kinetic models and forms of displacement. International Migration Review, 7.

LIEBRUCKS, A. 2001. The concept of social construction. Theory \& Psychology, 11(3):363-391.

McCLINTOCK, D., ISON, R. \& ARMSON, R. 2003. Metaphors for reflecting on research practice: research with people. Journal of Environmental Planning and Management, 46(5):715-731.

MÜLLER, J. 1996. Om tot verhaal te kom: Pastorale Gesinsterapie. Pretoria: RGN.

MÜLLER, J. 2004. HIVIAIDS, narrative practical theology, and postfoundationalism: the emergence of a new story. Unpublished article on www.julianmuller.co.nz Date of access: June 2004.

NEW ZEALAND IMMIGRATION SERVICES. 2003. Immigration fact pack. Issue 18. www.immigration.govt.nz.

O’DONNELL, K. 2003. Postmodernism. England: Lion.

OLLERENSHAW, JO ANNE \& CRESWELL, JOHN W. 2002. Narrative research: a comparison of two restorying data analysis approaches. Qualitative Inquiry, 8(3):329-347.

PERNICE, R., TRLIN, A., HENDERSON, A. \& NORTH, N. 2000. Employment and mental health of three groups of immigrants to New Zealand. New Zealand Journal of Psychology, 29(1).

PIETERSE, H.J.C. 2002. Prediking in 'n postmoderne lewensgevoel. Praktiese Teologie in Suid-Afrika, 17(1):76-103.

RENSHAW, D.C. 1989. The immigrant syndrome: uprooting and beyond. Proc. Inst. Chgo, 42(2).

SHAW, I.F. 2003. Ethics in qualitative research and evaluation. Journal of Social Work, 3(1):9-29.

SMYTH, W.E. \& MURRAY, M.J. 2000. Owning the story: ethical considerations in narrative research. Ethics \& Behavior, 19(2):311-340.

SOHN, L. 1983. Nostalgia. International Journal of Psycho-Analysis, 64.

STRAUSS, D.F.M. 2002. Voorvrae rondom die geloofwaardigheid van die Bybel in 'n "postmoderne tyd". Nederduitse Gereformeerde Teologiese Tydskrif, 43(3 \& 4):570-592.

VAN HUYSTEEN, J.W. 1997. Essays in postfoundationalist theology. Grand Rapids: Eerdmans 
VIAU, M. 1999. Practical theology: a new approach. Leiden Brill.

WESSELS, S. 2001. 'n Sisteemteoretiese studie van Suid-Afrikaners wat emigrasie beplan se voorstelling van sowel Suid-Afrika as die voorgenome land van verblyf. Pretoria: UP. (M.A.-verhandeling.)

\section{Kernbegrippe:}

\section{aanpassing}

narratiewe navorsing

postmodernisme

prakties-teologiese wysheid

sosiale konstruksionisme

verhuising na Nieu-Seeland

\section{Key concepts:}

\section{adaptation}

move to New Zealand

narrative research

postmodernism

practical theological wisdom

social constructionism 